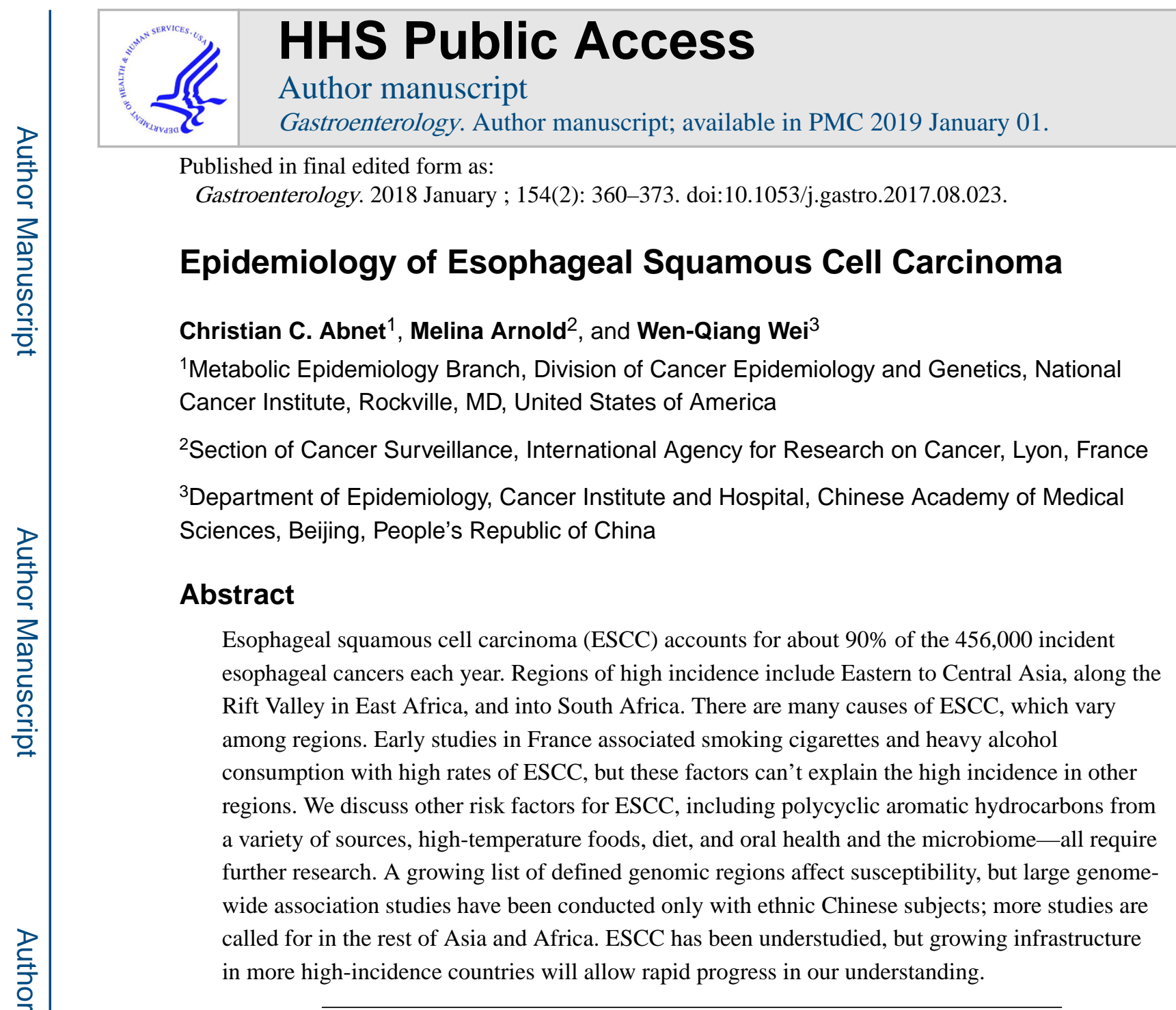

Esophageal cancer, the sixth leading cause of cancer death in the world, is a complex disease with many causes which differ by histologic type and the population it is found in ${ }^{1}$.

Esophageal squamous cell carcinoma (ESCC) and adenocarcinoma (EADC), have almost completely distinct geographic patterns, time trends, and primary risk factors. Patients with either cancer have a poor prognosis because of the late-stage at diagnosis for most patients. The causes of ESCC vary - the primary agents that cause ESCC in one population might not associated with this cancer in another. We briefly review the descriptive epidemiology of ESCC and review of confirmed and suspected risk factors.

\title{
Descriptive Epidemiology
}

The International Agency for Research on Cancer (IARC) estimates that there were about 450,000 cases of esophageal cancer in 2012: 88\% cases of ESCC and 12\% cases of EADC ${ }^{2}$. The geographic distribution of ESCC varies greatly, with more than 10-fold differences between countries (Figure 1). The highest incidence rates stretch from Eastern to Central Asia with another band running along the Indian Ocean coast of Africa along the Great Rift Valley. A third area with higher incidence was centralized around Uruguay in South America and encompassed the entire Gaucho Region of the continent, but lately the rates in Uruguay itself have decreased. 
Although there are differences in rates among countries, there are also notable differences within countries. This is well documented in China—cancer mortality was mapped at the county level in the 1970s, and although rates have decreased in recent years, they vary among regions ${ }^{3}$. Within China, rates of esophageal cancer can vary 10 -fold and there are sharp differences over short geographic distances (Figure 2). The most studied region of China is the North Central Taihung Mountain range. In small areas of this region, ESCC may be at or near the leading cause of death, with incidence rates exceeding 125/100,000/ year ${ }^{4}$. The large population of China and the high rates lead to China having about half of all ESCC cases on earth. These regions often have high incidence rates of gastric cardia adenocarcinoma and ESCC; these two cancers account for up 25\% of deaths in some areas. High rates of ESCC and gastric cardia adenocarcinoma are also reported in Northeastern $\operatorname{Iran}^{5}$, but there is no clear explanation for this phenomenon.

Overall, ESCC is more common in men $(69 \%)$ than women (31\%). However, this ratio varies among low-risk areas, like the United States (US) where the ratio of men:women can reach 4:1, and high-incidence areas of China and Iran, where the ratio is lower, approaching or even exceeding $1: 1^{2}$. About 12 countries are thought to have higher rates in women than men, including several in north east Africa and the Middle East. This variation in sex ratio likely reflects etiologic factors. Early studies from France ${ }^{6}$ and later studies from Western Countries showed that risk for ESCC is increased by smoking tobacco and heavy consumption of alcoholic beverages. These behaviors were historically more prevalent in men than in women. In high-incidence areas, tobacco and alcohol may contribute little (or not at all) to ESCC incidence, because they are rarely used in the population (e.g. alcoholic beverages in Iran). In these areas, key risk factors are less well described, but seem to be less sex-dependent.

Over the last 40 years there have been large changes in the incidence in the different types of esophageal cancers, and these trends are region specific. In the US ${ }^{7}$ (Figure 3), Europe ${ }^{8}$, Australia, and many other Western countries, the incidence of ESCC had been decreasing for several decades, whereas the incidence of adenocarcinoma has increased. In Eastern Europe $^{8}$, Japan, and South America, ESCC still predominates ${ }^{2}$. In most of Asia and SubSaharan Africa, esophageal carcinomas occur almost exclusively as ESCCs. As noted, the co-occurrence of gastric cardia adenocarcinoma in populations with high incidence of $\mathrm{ESCC}^{5,9}$ creates challenges to tracking esophageal adenocarcinoma, since there is no definitive system for separating adenocarcinomas than span the esophago-gastric junction.

Within countries, the proportion of ESCC and EADC can vary greatly among population subgroups. For example, in the US, African-Americans are 7-fold more likely to be diagnosed with ESCC than EADC, whereas US whites are about 4-fold more likely to develop EADC than $\mathrm{ESCC}^{7}$. The reasons for this large difference are not clear and can't be fully explained by known risk factors ${ }^{10}$.

The ESCC incidence is decreasing in many Western countries, especially among men, probably due to decreased smoking prevalence. But these decreases are not universal. For example, the IARC projects almost no change in the rates of ESCC in Australian, Japanese, or UK men between now and $2030^{11}$. Incidence rates might increase in women in these 
same some countries, likely due to women's later peak in cigarette smoking rates and possibly due to changing social mores regarding alcoholic beverage consumption by women. Furthermore, the number of cancer cases is unlikely to decrease even in the presence of falling rates, because of the growing and aging populations in developing countries, which have most ESCC cases.

\section{Known and Suspected Risk Factors}

The etiology of ESCC is multi-factorial and strongly population dependent. A study in the US estimated a population-attributable risk of $89 \%$ using only cigarette smoking, alcoholic beverage consumption, and low consumption of fruits and vegetables ${ }^{12}$. In contrast, a large cohort study conducted in a high-incidence region of China found that tobacco smoking had little role in ESCC etiology and that modest alcohol consumption was associated with lower risk of the disease than in non-consumers ${ }^{13}$. This lack of effects seems to be explained partly by lower exposure rates, but our understanding remains incomplete. Given these large differences in etiology, population-specific estimates are needed for all risk factors and we can draw few conclusions that apply to ESCC globally. A summary of risk factors with the strongest evidence is provided in Table 1; these have been divided into those confirmed by formal review groups and those for which the level of evidence is not yet strong enough to consider them confirmed.

\section{Socioeconomic status (SES)}

SES is a complex construct representing many aspects of the human condition, yet it is one of the most consistent risk factors for ESCC—even after comprehensive adjustment for tobacco, alcohol, age, and many other potential risk factors. In Western countries, where studies often include people with a wide range of educational histories and income, SES is still associated with larger risks than might be expected. For example, in Sweden, notable differences in risk are associated with working in a manual trade or having less than a high school education ${ }^{14}$ and in the US a statistically significant association was evident with income ${ }^{15}$. What may be more surprising is that similar associations were observed in studies conducted in economically developing populations with compressed social status among participants ${ }^{13,16,17}$, some which only included subsistence farmers. It can be a challenge to use SES as either a main effect or as a confounder in models that examine other exposures, given the multi-dimensional nature of the construct. One promising method uses multiple correspondence analysis to build a composite wealth score from many underlying correlated SES indicators ${ }^{18}$. This provides a single coherent variable and reduces the role of chance and correlation among SES indicator selection. In sum, we don't know how SES affects risk, but this is an important question that does not appear to be solely a problem of residual confounding from known risk factors.

\section{Tobacco}

Tobacco smoking and chewing are large risk factors for ESCC in economically developed countries. These account for a large proportion of population-attributable risk ${ }^{12}$ (an approximate 3-9-fold relative risk [RR] in current smokers) ${ }^{19-21}$. But relatively weaker effects and lower attributable risk $^{22}$ have been reported in economically-developing 
countries (RR of approximately 1.5$)^{13,16,23,24}$. In addition to cigarettes, there are other forms of tobacco for use, such as pipe, cigar, hookah, and chewing tobacco. Pipe and cigar have been demonstrated to convey risks similar risk to cigarettes ${ }^{25}$. Hookah and other forms of water pipe historically were predominantly used in the Middle-Eastern countries, but of late are becoming popular with young people worldwide. Meta-analyses reported pooled odds ratio of $3-4^{26,27}$, but there is little consistency in the risks estimates, so the true risk associated with water pipe requires further investigation. Some studies reported that certain types of chewed tobacco carry risk of a magnitude greater than cigarettes or water pipe ${ }^{23,28}$, but the forms of chewed tobacco and the adjuvants used in the preparations vary among countries-a complete picture of the risk will require population-specific estimates.

Both exposure intensity and duration have been reported to be relevant for risk of ESCC conveyed by smoking tobacco ${ }^{13,20,21}$. A detailed analysis of these 2 aspects of exposure showed an inverse delivery rate pattern, whereby for equal pack-years smoking more cigarettes/day for shorter duration was less harmful than smoking fewer cigarettes/day for longer duration ${ }^{29}$, highlighting the importance of duration and the potential harm that may arise from even very modest intensity but long standing tobacco smoking ${ }^{30}$.

Tobacco-specific nitrosamines (TSNA) and polycyclic aromatic hydrocarbons (PAH) are thought to be the major carcinogenic substances in tobacco. The Shanghai Cohort Study revealed that Chinese smokers were exposed to less TSNA compared with U.S. smokers ${ }^{31}$. But these investigators also reported that the urinary concentration of N'-nitrosonornicotine was very strongly linked to ESCC risk and inferred that this may the causative agent in these tobacco smokers ${ }^{32}$.

\section{Alcoholic beverages}

Alcoholic beverage consumption has been causally linked to ESCC by IARC ${ }^{33}$ and the World Cancer Research Fund ${ }^{4}$. Alcohol might increase risk for ESCC because acetaldehyde, a class 1 carcinogen, is the first metabolite of ethanol metabolism ${ }^{34,35}$. Microorganisms in oral cavity also produce acetaldehyde from ethanol and could contribute to alcohol's carcinogenic effects ${ }^{36-38}$. Alcoholic beverages and other foods ${ }^{39}$ can also contain acetaldehyde, leading to direct exposure without ethanol metabolism.

Most epidemiologic studies have confirmed that alcoholic beverages are a risk factor for ESCC in economically developing and developed areas, although their carcinogenic effects vary with degree of consumption. Alcohol consumption increased the risk of ESCC by 1.6to 5.3-fold in Asian countries including China ${ }^{40-47}, \operatorname{Iran}^{23}$, Japan ${ }^{40}$, and India ${ }^{48,49}$, and about 3-fold in Africa ${ }^{50-53}$ and South America ${ }^{54-57}$. In many areas with low incidence rates of ESCC, however, the relationship between alcohol and ESCC is notably stronger, with about 6-fold increase in risk in Europe ${ }^{58-64}$ and 9-fold in North America among consumers of alcohol ${ }^{10,65-67}$. Drinking patterns have been understudied and the risks associated with binge drinking are important to investigate. The population-attributable fraction of ESCC due to alcoholic beverages was reported to be large $(72.4 \%)$ in the US, but much lower in China (10.9\%), which could be due to differences in levels of exposure ${ }^{12,22}$. 
Even though alcohol intake is strongly associated with ESCC in most studies, a J-shaped rather than linear relationship was found between alcohol consumption and ESCC risk in many previous studies ${ }^{10,58,68,69}$. The Million Women Study associated low alcohol intake ( $<70 \mathrm{~g} /$ week) with a decreased risk of ESCC; heavy intake of alcohol ( $<150 \mathrm{~g} /$ week) increased the risk significantly ${ }^{70}$. Whether this reduced risk with moderate intake is real or due to unmeasured confounders has not been established. Many cohort studies only collect data on current or recent alcohol consumption. Future studies should include data on lifetime alcohol exposure, to allow full modelling of this important exposure. Given the apparent different associations between alcohol and risk of ESCC (possible J-shaped but clearly high risk with high intake), breast cancer (modest linear increased risk), and kidney cancer (strong reduction in risks with increasing intake even at high levels), for example, it seems likely that different mechanisms are involved at different organ sites.

Tobacco and alcohol may interact to increase the risk of ESCC compared with the predicted multiplicative risk of either one alone ${ }^{71}$. Although many studies have reported interactions, some large cohort studies have not found evidence for this effect modification ${ }^{19}$. Cohort members tend to have healthier lifestyles than subjects enrolled through population-based case-control studies; the lack of interaction observed in cohort studies may be due to the low number of heavy consumers of alcohol. Nevertheless, even without an interaction, heavy consumption of alcohol paired with tobacco consumption greatly increases risk of ESCC.

\section{PAHs}

PAHs cause cancer at multiple sites through some exposure routes. Exposure to high levels of PAHs from non-tobacco sources could mask the effects of PAHs from cigarettes. So the apparently lower risk ESCC among tobacco smokers in some populations may be due to PAHs from other sources. Iranian ${ }^{72}$, Chinese ${ }^{73}$, and Brazilian ${ }^{74}$ high-risk populations have high exposure to PAHs - even non-smokers. The PAHs could come from certain foods, beverages, or cooking and heating methods. This exposure seems to be a constant among populations in economically developing countries with high incidences of ESCC. A casecontrol study measured PAH exposure in normal esophageal tissues of cases and controls and reported odds ratios more than 25 for the most-exposed quintile ${ }^{75}$. This finding strongly implicates PAHs in esophageal squamous cell carcinogenesis, but confirmation in prospective studies is required.

\section{Betel quid}

Betel quid consists of a betel leaf wrapped around areca nut with or without tobacco and other additives. Chewing betel quid is common in South and South-East Asian countries. The IARC has confirmed it as a risk factor for $\mathrm{ESCC}^{76}$. Betel quid chewing is common in South and South-East Asian countries, with the independent relative risk values of approximate $2.2-5.6^{77-80}$. The combination of betel quid and tobacco increases relative risk by 2.3 - to 3.5 -fold compared to betel quid alone ${ }^{78,79}$. Betel quid chewers in some populations are also frequently tobacco smokers ${ }^{77}$-betel and tobacco might have synergistic effects on ESCC risk ${ }^{77,78}$. 
Diet

Numerous studies of many designs in different locales have examined whether diet, foods, or specific nutrients are associated with ESCC risk. Broader measures of diet quality using pre-specified indices, such as the Healthy Eating Index, may be a useful construct for assessing dietary effects within a population and adherence has been associated with lower risk of $\mathrm{ESCC}^{81}$. But poor diet can be strongly confounded by other important risk factors already discussed including tobacco smoking, alcoholic beverage consumption, and low SES. And given the substantial etiologic heterogeneity for ESCC, drawing strong conclusions for dietary factors is further challenged by population differences in other major risk factors.

Many cohort studies have failed to associate individual foods or nutrients with ESCC riskeven those in populations that appear to be deficient in the tested nutrients. This appears to mean that it is not poor diet in general that increases risk of ESCC. Rather, either any real effects on risk are probably mediated by a limited list of specific agents that have not been appropriately tested, or by small contributions from a wide variety of different foods. Conclusive evidence for specific nutrients could lead to prevention strategies that involve fortification, supplementation, avoidance, or reformulation. It is important to remember that regardless of whether specific dietary agents affect risk of ESCC, diet affects risk for many diseases, and except in the most highly affected populations, dietary choices should probably be based on their effect on overall health and mortality—not risks of individual cancers ${ }^{82}$.

\section{Vegetables and fruits}

Systematic review of all studies of diet and cancer risk concluded that higher intake of fruits and vegetables probably decreases the risk of esophageal cancer. Each increment of $50 \mathrm{~g} / \mathrm{day}$ of raw vegetables was associated with $31 \%$ decrease in risk of esophageal cancer, while the same increment intake of fruit was associated with $22 \%$ decrease $^{12}$. However, these estimates for fruits and vegetables may be over-estimates because much of the evidence comes from case-control studies, which are more susceptible to bias than cohort studies. The Continuous Update Project for the esophagus concluded that the evidence supporting greater consumption of vegetables decreases the risk of ESCC is "limited", which was downgraded from "probable" in the Second Expert Report ${ }^{4}$. Each increment of $100 \mathrm{~g} /$ day of vegetables was associated with reduced risk of ESCC by $9 \%$ (non-significant), whereas the same increment intake of fruit was associated with reduced risk by $16 \%$ (significant) ${ }^{4}$. Increasing variety in consumption of vegetables and fruits combined and fruit consumption alone was associated with a $12 \%$ and $24 \%$ reduction in risk of ESCC, respectively-at least among smokers $^{83}$.

\section{Pickled vegetables}

Asian pickled vegetables could contribute to development of ESCC and gastric cancer ${ }^{84,85}$. In high-risk areas of China, pickled vegetables were an integral part of the diet in many families and eaten 9-12 months a year ${ }^{9}$. The vegetable pickling process could generate potentially carcinogenic mycotoxins and $\mathrm{N}$-nitroso compounds $9,86,87$. The mutagenicity and carcinogenicity of pickled vegetables have been shown in some animal and in vitro studies $^{86,88}$. An IARC Working Group concluded that there was limited evidence from 
humans and inadequate evidence from experimental animals to support the carcinogenicity of pickled vegetables ${ }^{89}$. A meta-analysis associated intake of pickled vegetables with a 2fold higher risk of $\mathrm{ESCC}^{90}$. Well-designed prospective studies are warranted, as most data come from retrospective studies with high heterogeneity in the results.

\section{Micronutrients}

There is evidence from mechanistic and human studies that micronutrients, including vitamin A, retinol, thiamin, riboflavin, calcium, iron, zinc, pro-vitamin A carotenoids, or $\beta$ cryptoxanthin, contribute to development of $\mathrm{ESCC}^{91-97}$. Evidence for these exposures was judged as "limited - no conclusion". It is noteworthy that nutrient supplements are not currently recommended for ESCC prevention in the general population ${ }^{94,98}$. A 6-year randomized trial conducted in China showed that multivitamins did not reduce risk in a subpopulation of persons at high risk for ESCC or affected any other endpoint examined ${ }^{99}$. This negative result is particularly notable given the low nutrient status of this population, which should be the most likely to benefit from these agents, and the long-post intervention followup time, which could have detected late effects.

In contrast, there is increasing evidence that selenium and riboflavin affect risk of ESCC-at least in some populations of low nutritional status for these nutrients. High exposure to selenium has been associated with decreased risk of ESCC ${ }^{100-104}$. The Nutrition Intervention Trial conducted in the general population of Linxian, China, a region with epidemic rates of ESCC and nutritional deficiencies showed that riboflavin and niacin daily supplement reduced risk of esophageal cancer by $14 \%$ (non-significant) after 5.25 years intervention ${ }^{105}$. A 10-year follow-up study showed selenium, $\beta$-carotene, and $a$-tocopherol supplements significantly reduced risk of esophageal cancer death by $17 \%$, but only among participants younger than 55 years old ${ }^{106}$. Analogous to the hypothesis for folate and colorectal cancer this age interaction may suggest that selenium might prevent ESCC only when it is supplemented before advanced preneoplasia is evident. An independent chemoprevention trial focused on precancerous lesion reported that selenium could increase regression and reduce regression in subjects with mild esophageal squamous dysplasia ${ }^{107}$.

\section{Hot food and beverages}

Consumption of hot food and beverages has been associated with increased risk of ESCC in multiple studies ${ }^{18}$. Numerous case-control studies in Uruguay and the Gaucho Region of South America reported increased risk in subjects that drink the traditional herbal beverage maté, which is consumed in large volumes (several liters per day) at high temperature ${ }^{108}$. One limitation of these studies was their use of a non-validated qualitative questionnaire. Several recent studies have used quantitative measurements of temperature of drinks; these found that in several high-incidence areas, typical temperatures are extraordinarily high, including in Iran ${ }^{109}$ and in Tanzania ${ }^{110}$. In Tanzania, the mean temperature at first sip exceeded $70^{\circ} \mathrm{C}$, which would carry a high risk based on the study from Iran. The good news is that the adverse risk of high temperature beverages and foods might be at least partially mitigated by modestly lowering the temperature of consumption rather than avoiding consumption altogether. This would seem to be a more achievable public health goal than asking people to stop consuming beverages that have important roles in many local cultures. 
Most studies of coffee have found no adverse associations, but this may be because few people in heavy coffee-consuming cultures drink it at a temperature above $60^{\circ} \mathrm{C}$. Studies in animal models of ESCC showed that high-temperature water can potentiate the effects of chemical carcinogens, through thermal irritation; ${ }^{111}$ this potentiation is thought to be the primary method of action. Several recent studies have called into question whether the adverse effects of maté on risk of esophageal cancer might also be mediated by contamination with PAHs ${ }^{112}$. Reports that high consumption of maté may be associated with increased risk at tumor sites without contact with the hot beverage, such as the bladder and kidney, provide support for this hypothesis ${ }^{113}$.

\section{Body mass index (BMI)}

Increased BMI is frequently associated with a lower risk of $\mathrm{ESCC}^{114,115}$. However, this association is routinely and plausibly attributed to the combined effects of undiagnosed cancer and frank or incipient dysphagia leading to weight loss. However, long-term followup studies of ESCC have reported this association is evident decades before cancer diagnosis $^{116}$, so reverse causation might not be an explanation. It is important to determine the association between BMI at young ages and the risk of ESCC. One study using recalled body size from youth reported an association between higher body weights and ESCC risk, but there have been few studies of this hypothesis ${ }^{117}$.

Alternatively, BMI may reflect another physiologic process associated with an etiologically relevant exposure. BMI has a similar association with respiratory disease death that can be detected many years before death ${ }^{118}$ and is clearly not caused by dysphagia. Fine particulate matter (such as $\mathrm{PM}_{2.5}$ ) has been linked to chronic obstructive pulmonary disease. ${ }^{119}$ Many particles carry carcinogenic substances ${ }^{120}$. Exposure to indoor air pollution is common and has been associated with ESCC risk in many populations with high incidence of $\mathrm{ESCC}^{121,122}$. Indoor air pollution might induce weight loss linked to chronic obstructive pulmonary disease and ESCC upon exposure to carcinogens.

\section{Reproductive factors}

The male predominance of ESCC can be mostly accounted for by differences between sexes in exposure to risk factors such as tobacco smoking and alcohol consumption in Western countries, but hormonal factors should be investigated. A few studies have examined factors such as parity, breast feeding, menopause, or use of tamoxifen ${ }^{123-125}$ and found some apparently protective effects that could be interpreted as benefit from exposure to estrogen. However, a study in Sweden showed that parity and age at first birth show the same protective associations in men and women. So, associations may be due to confounding by socioeconomic status or other non-hormonal factors ${ }^{126}$.

\section{Medical conditions}

Several medical conditions have been associated ESCC risk, such as Plummer Vinson Syndrome (symptoms include iron deficiency anemia and webbing of esophageal membranes) ${ }^{127}$ and Fanconi Anemia (an inherited bone marrow failure linked to several cancers $)^{128}$. Although the relative risks may be very large, the absolute risks are low, as would be the contribution of these cases to the overall burden of ESCC. A long-term follow- 
up study of 448 patients with achalasia (an esophageal motility disorder) in the Netherlands ${ }^{129}$ found 15 patients (3.3\%) had developed EC with a mean time to cancer diagnosis after presentation of 11 years. This resulted in a relative risk for ESCC of 28 and an incidence rate of $0.34 \% / y e a r$. Esophageal cancer risk is also increased in persons exposed to therapeutic radiation for other medical conditions, such as breast cancer ${ }^{130}$.

\section{Poor oral health}

Poor oral health, including tooth loss, the frequency of teeth brushing, and poor periodontal health has been examined as a potential risk factor of ESCC ${ }^{16,131}$. However, too few epidemiologic studies have investigated the potential association between oral hygiene and ESCC worldwide to draw final conclusions. There is evidence from case-control and cohort studies that people with more lost teeth have an approximate 1.5-fold increase in risk of ESCC. Regular tooth brushing has been reported to associate with reduced risk of ESCC in several studies ${ }^{132}$, including studies conducted in China ${ }^{16,131}$ Iran $^{133}$, Kenya $^{53}$ and India ${ }^{134}$, whereas tooth loss was not significantly associated with ESCC in the US ${ }^{135}$ or Europe $^{135,136}$. Proposed mechanisms for the association between poor oral health and ESCC include the potential for inflammation associated with periodontal disease to have distant effects. Alternatively, the microbiota associated with periodontal disease and poor oral hygiene might produce secondary metabolites such as acetaldehyde and reactive nitrate and nitrite-precursors to nitrosamines, ${ }^{137}$ which are carcinogens associated with ESCC.

\section{Microbiome}

The Human Microbiome Project and the availability of inexpensive high-throughput sequencing, has revolutionized the direct study of the role of the human microbiome on human health and disease. The richness, diversity, and exact composition of microbiota in different organs might contribute to development of ESCC. There have been a few studies of associations between the upper digestive tract microbiota and ESCC.

People with lower esophageal microbial richness and saliva microbial diversity may be more prone to develop esophageal squamous dysplasia ${ }^{138}$ (the precursor of ESCC) and ESCC $^{139}$, respectively in China. Increased richness of Clostridiales and Erysipelotrichales in the gastric corpus might contribute to esophageal squamous dysplasia and $\mathrm{ESCC}^{140}$ in Iran. Furthermore, Porphyromonas gingivalis, an important periodontal disease pathogen, was detected in $61 \%$ of ESCC tissues but not in tissues from healthy subjects. So, P gingivalis could affect risk for $\mathrm{ESCC}^{141}$. Prospective cohort studies, ideally with repeat sampling from multiple organ sites, including the mouth esophagus, stomach, and stool, will be necessary to investigate the role of the microbiota in ESCC and other gastrointestinal cancers and disease.

\section{Human papilloma virus (HPV)}

Numerous studies have attempted to assess whether HPV is an etiologic agent for ESCC. Studies that test for the presence of HPV DNA in ESCC tumor tissue have reported a wide range of prevalence estimates, ranging from 0 to nearly $70 \%{ }^{142}$, but detecting HPV DNA in the tumor does not mean that it causes tumorigenesis or tumor development. 
A large international consortium performed serologic analyses of L1 and E6/E7 to assess the role of HPV in ESCC etiology ${ }^{143}$. Antibodies to E6/E7 are generally considered necessary to determine that a cancer is caused by HPV. This study identified only 4 ESCC samples (0.3\% of those tested) that tested positive for HPV16 E6 and E7. This finding indicates a limited role, if any, for HPV in ESCC. A follow-up study of tissue samples confirmed the lack of association between ESCC and HPV DNA, HPV mRNA, or p16(INK4a) upregulation ${ }^{144}$. Studies that sequenced genomes of ESCC samples from diverse countries did not find evidence for integrated HPV DNA ${ }^{145,146}$. Altogether, evidence indicates that if HPV is an etiologic agent for ESCC, the number of cases caused by these viruses is very low - HPV vaccines are not likely to prevent ESCC.

\section{Genetic Factors}

There is long-standing indirect evidence for an inherited component to ESCC etiology. Many studies of genetic factors have reported that a family history of ESCC increases the risk for an incident cancer ${ }^{147,148}$. Of course, family history comprises a mixture of inherited genes and habits, which are partly determined by genetic factors. The clearest example is tobacco smoking, where the habit is more likely among persons raised with tobacco smokers, but there is also a genetic component to tobacco addiction.

Many diseases are caused by defects in a small number of genes, with Mendelian patterns of inheritance. For ESCC, one of the clearest links is to tylosis. Tylosis is a rare genetic disease characterized by palmoplantar keratoderma (thickening of the skin on the palms and soles of the feet). The genetic basis for tylosis has been elucidated to the point that versions with and without risk of esophageal cancer risk have now been defined. Tylosis with esophageal cancer has been linked to the autosomal dominant mutations in RHBDF2 gene at $17 \mathrm{q} 25^{149}$. ESCC risk is high in these subjects, with a young age at onset and penetrance estimated to be as high as $90 \% 150$.

Other familial syndromes have also been linked to increased risk of ESCC, including the inherited bone marrow failure syndrome Fanconi Anemia ${ }^{128}$. Although relative risks for esophageal cancer are high in this group, competing risk for other causes of death, avoidance of high risk behaviors such as tobacco smoking and heavy alcohol drinking, and the young age at onset of these competing risks leads to low absolute risks.

The history of studies of high-prevalence but low-penetrance genetic variants that affect risk for ESCC is similar to that of most diseases. Development of inexpensive genotyping technologies has resulted in many small case-control analyses of individual singlenucleotide polymorphisms (SNPs). Most of these have not produced reproducible results, with one notable exception. Alcoholic beverage consumption and ESCC risk are associated with a well-known phenomenon known as flushing ${ }^{151}$. Flushing occurs in some individuals of East Asian origin when they consume alcoholic beverages. This response occurs because individuals with specific variants in the aldehyde dehydrogenase 2 family gene ( $A L D H 2)$ and an acetaldehyde dehydrogenase gene $(A D H 1 B)$ produce high concentrations of acetaldehyde during consumption of alcohol. The flushing response is unpleasant, so individuals heterozygous for this variant in $A L D H 2$ tend to avoid alcohol consumption, 
whereas individuals who are homozygotes for this variant rarely, if ever, consume alcohol; they have a low risk for alcohol-linked diseases including alcoholism. If people carrying these polymorphic variants consume alcohol, their risk of ESCC increases as high as 43-fold for moderate drinkers and 73 -fold for heavy drinkers ${ }^{152}$. Individuals with this variant in $A L D H 2$ who do not consume alcohol have no increase in risk for $\mathrm{ESCC}^{153}$.

High-throughput genotyping enabled efficient characterization of the associations between common genetic variants and risk of many diseases by what has come to be known as genome wide association studies (GWAS). Three large studies of people of Chinese descent have published results alone and in combination ${ }^{153-158}$, whereas a single study of European subjects included a moderate number of esophageal cancer cases ${ }^{159}$. Collectively these studies have identified several genomic regions associated with ESCC (Table 1). GWAS studies alone can't identify the functional polymorphisms, so although the nearest gene is often used to describe these findings, one should not assume that that gene is the cause of the differential risk.

The main effects from the Chinese studies have revealed several key SNPs, most notably variants in the phospholipase c epsilon 1 gene (PLCE1). Remarkably, this SNP is also strongly related to risk of gastric cardia cancer, increasing our understanding the cooccurrence of these tumors of different cell types that develop in adjoining organs ${ }^{153,155}$. This gene has been knocked out in mice and appears to have multiple roles in modulating carcinogen effects. Mice without this gene are less susceptible to PAH-induced skin cancers ${ }^{160}$ and genetically induced colon tumors ${ }^{161}$. Further elucidation of the mechanism of action of this variant is important.

Other identified variants have included genomic regions linked to other cancers including, the region of the caspase 8 gene- a complex region with cancer risk linked to variants in several in-line linkage disequilibrium blocks. One notable finding was the risk of ESCC linked to a polymorphism in the TP53 gene region ${ }^{157}$. Somatic mutations in this gene are a common feature of ESCC and many other tumors, but common SNPs in the gene have not been linked to other cancers.

Another notable finding from the combined analysis of the three published Chinese GWAS $^{157}$ is the apparent association between a variant in the HLA 2 genome region and ESCC risk, at least among subjects collected in the high-incidence Taihung Mountain region of China. Few risk factors specific to this geographic region have been discovered. The HLA region has very complex and long-range linkage disequilibrium patterns that require extensive and detailed follow-up analyses. Further elucidation of this HLA region and its role in ESCC remains a research priority.

Outside these GWAS studies, there has been little progress in understanding the role of common genetic variants and ESCC risk. A few studies have re-examined these polymorphisms in other populations, including a study of polymorphisms in PLCE1 in South Africa ${ }^{162}$, a region with high rates of ESCC. That study highlighted the complexity of translating and testing findings from one population to another, given the need to resequence the local region to design genotyping assays. Ideally, large GWAS will be carried 
out in each high-risk population to provide local results, which can be combined to increase our overall understanding of ESCC pathogenesis. Without this sort of comprehensive assessment, we will not realize the full potential for common genetic variants to help us understand the etiology of ESCC in different populations, nor the potential for these variants to play a role in risk stratification as is being realized in breast cancer ${ }^{163}$.

\section{Future Directions}

Many Western countries have a decreasing incidence of ESCC, likely due to decreases in tobacco consumption and some moderation in heavy consumption of alcohol. However, ESCC remains a major cause of cancer death worldwide, with greater incidence values than cancers of the pancreas, prostate, cervix, or other tissues (http://globocan.iarc.fr). The concentration of ESCC in impoverished populations with limited research infrastructure has been a major impediment to progress, but studies in Iran ${ }^{164}$, East Africa ${ }^{165}$, India ${ }^{28}$, and elsewhere have added to findings from decades-long research in China. These continued studies should lead to a deeper understanding of the highly fatal and understudied cancer that primarily afflicts our poorest people.

\section{References}

1. Ferlay, JSI., Ervik, M., Dikshit, R., Eser, S., Mathers, C., Rebelo, M., Parkin, DM., Forman, D., Bray, F. GLOBOCAN 2012 v1.0, Cancer Incidence and Mortality Worldwide: IARC CancerBase No. 11. Lyon, France: International Agency for Research on Cancer; 2013.

2. Arnold M, Soerjomataram I, Ferlay J, et al. Global incidence of oesophageal cancer by histological subtype in 2012. Gut. 2015; 64:381-7. [PubMed: 25320104]

3. Chen W, Zheng R, Baade PD, et al. Cancer statistics in China, 2015. CA Cancer J Clin. 2016; 66:115-32. [PubMed: 26808342]

4. Blot WJ, Li JY. Some considerations in the design of a nutrition intervention trial in Linxian, People's Republic of China. Natl Cancer Inst Monogr. 1985; 69:29-34. [PubMed: 3914622]

5. Islami F, Kamangar F, Aghcheli K, et al. Epidemiologic features of upper gastrointestinal tract cancers in Northeastern Iran. Br J Cancer. 2004; 90:1402-6. [PubMed: 15054463]

6. Tuyns AJ, Masse G. Cancer of the oesophagus in Brittany: an incidence study in Ille-et-Vilaine. Int J Epidemiol. 1975; 4:55-9. [PubMed: 1116895]

7. Cook MB, Chow WH, Devesa SS. Oesophageal cancer incidence in the United States by race, sex, and histologic type, 1977-2005. Br J Cancer. 2009; 101:855-9. [PubMed: 19672254]

8. Steevens J, Botterweck AA, Dirx MJ, et al. Trends in incidence of oesophageal and stomach cancer subtypes in Europe. Eur J Gastroenterol Hepatol. 2010; 22:669-78. [PubMed: 19474750]

9. Yang CS. Research on esophageal cancer in China: a review. Cancer Res. 1980; 40:2633-44. [PubMed: 6992989]

10. Brown LM, Hoover R, Silverman D, et al. Excess incidence of squamous cell esophageal cancer among US Black men: role of social class and other risk factors. Am J Epidemiol. 2001; 153:11422. [PubMed: 11159155]

11. Arnold M, Laversanne M, Morris Brown L, et al. Predicting the future burden of esophageal cancer by histological subtype: International trends in incidence up to 2030. American Journal of Gastroenterology. 2017 in press.

12. Engel LS, Chow WH, Vaughan TL, et al. Population attributable risks of esophageal and gastric cancers. J Natl Cancer Inst. 2003; 95:1404-13. [PubMed: 13130116]

13. Tran GD, Sun XD, Abnet CC, et al. Prospective study of risk factors for esophageal and gastric cancers in the Linxian general population trial cohort in China. Int J Cancer. 2005; 113:456-63. [PubMed: 15455378] 
14. Jansson C, Johansson AL, Nyren O, et al. Socioeconomic factors and risk of esophageal adenocarcinoma: a nationwide Swedish case-control study. Cancer Epidemiol Biomarkers Prev. 2005; 14:1754-61. [PubMed: 16030113]

15. Gammon MD, Schoenberg JB, Ahsan H, et al. Tobacco, alcohol, and socioeconomic status and adenocarcinomas of the esophagus and gastric cardia. J Natl Cancer Inst. 1997; 89:1277-84. [PubMed: 9293918]

16. Wei WQ, Abnet CC, Lu N, et al. Risk factors for oesophageal squamous dysplasia in adult inhabitants of a high risk region of China. Gut. 2005; 54:759-63. [PubMed: 15888779]

17. Dar NA, Shah IA, Bhat GA, et al. Socioeconomic status and esophageal squamous cell carcinoma risk in Kashmir, India. Cancer Sci. 2013; 104:1231-6. [PubMed: 23721087]

18. Islami F, Boffetta P, Ren JS, et al. High-temperature beverages and foods and esophageal cancer risk--a systematic review. Int J Cancer. 2009; 125:491-524. [PubMed: 19415743]

19. Freedman ND, Abnet CC, Leitzmann MF, et al. A prospective study of tobacco, alcohol, and the risk of esophageal and gastric cancer subtypes. Am J Epidemiol. 2007; 165:1424-33. [PubMed: 17420181]

20. Zendehdel K, Nyren O, Luo J, et al. Risk of gastroesophageal cancer among smokers and users of Scandinavian moist snuff. Int J Cancer. 2008; 122:1095-9. [PubMed: 17973262]

21. Ishiguro S, Sasazuki S, Inoue M, et al. Effect of alcohol consumption, cigarette smoking and flushing response on esophageal cancer risk: a population-based cohort study (JPHC study). Cancer Lett. 2009; 275:240-6. [PubMed: 19036500]

22. Wang JB, Fan JH, Liang H, et al. Attributable causes of esophageal cancer incidence and mortality in China. PLoS One. 2012; 7:e42281. [PubMed: 22876312]

23. Nasrollahzadeh D, Kamangar F, Aghcheli K, et al. Opium, tobacco, and alcohol use in relation to oesophageal squamous cell carcinoma in a high-risk area of Iran. Br J Cancer. 2008; 98:1857-63. [PubMed: 18475303]

24. Okello S, Churchill C, Owori R, et al. Population attributable fraction of Esophageal squamous cell carcinoma due to smoking and alcohol in Uganda. BMC Cancer. 2016; 16:446. [PubMed: 27400987]

25. Koop CE, Luoto J. "The Health Consequences of Smoking: Cancer," overview of a report of the Surgeon General. Public Health Rep. 1982; 97:318-24. [PubMed: 7111654]

26. Montazeri Z, Nyiraneza C, El-Katerji H, et al. Waterpipe smoking and cancer: systematic review and meta-analysis. Tob Control. 2017; 26:92-97. [PubMed: 27165994]

27. Awan KH, Siddiqi K, Patil S, et al. Assessing the Effect of Waterpipe Smoking on Cancer Outcome - a Systematic Review of Current Evidence. Asian Pac J Cancer Prev. 2017; 18:495-502. [PubMed: 28345836]

28. Dar NA, Bhat GA, Shah IA, et al. Hookah smoking, nass chewing, and oesophageal squamous cell carcinoma in Kashmir, India. Br J Cancer. 2012; 107:1618-23. [PubMed: 23033008]

29. Lubin JH, Cook MB, Pandeya N, et al. The importance of exposure rate on odds ratios by cigarette smoking and alcohol consumption for esophageal adenocarcinoma and squamous cell carcinoma in the Barrett's Esophagus and Esophageal Adenocarcinoma Consortium. Cancer Epidemiol. 2012; 36:306-16. [PubMed: 22504051]

30. Inoue-Choi M, Liao LM, Reyes-Guzman C, et al. Association of Long-term, Low-Intensity Smoking With All-Cause and Cause-Specific Mortality in the National Institutes of Health-AARP Diet and Health Study. JAMA Intern Med. 2017; 177:87-95. [PubMed: 27918784]

31. Yershova K, Yuan JM, Wang R, et al. Tobacco-specific N-nitrosamines and polycyclic aromatic hydrocarbons in cigarettes smoked by the participants of the Shanghai Cohort Study. Int J Cancer. 2016; 139:1261-9. [PubMed: 27163125]

32. Yuan JM, Knezevich AD, Wang R, et al. Urinary levels of the tobacco-specific carcinogen N'nitrosonornicotine and its glucuronide are strongly associated with esophageal cancer risk in smokers. Carcinogenesis. 2011; 32:1366-71. [PubMed: 21734256]

33. Cancer IAfRo. Volume 100E: Personal Habits and Indoor Combustions. Volume International Agency for Research on Cancer; Lyon, France: 2012. 
34. Ohashi S, Miyamoto S, Kikuchi O, et al. Recent Advances From Basic and Clinical Studies of Esophageal Squamous Cell Carcinoma. Gastroenterology. 2015; 149:1700-15. [PubMed: 26376349]

35. Liu Y, Chen H, Sun Z, et al. Molecular mechanisms of ethanol-associated oro-esophageal squamous cell carcinoma. Cancer Lett. 2015; 361:164-73. [PubMed: 25766659]

36. Homann N, Jousimies-Somer H, Jokelainen K, et al. High acetaldehyde levels in saliva after ethanol consumption: methodological aspects and pathogenetic implications. Carcinogenesis. 1997; 18:1739-43. [PubMed: 9328169]

37. Salaspuro MP. Acetaldehyde, microbes, and cancer of the digestive tract. Crit Rev Clin Lab Sci. 2003; 40:183-208. [PubMed: 12755455]

38. Muto M, Hitomi Y, Ohtsu A, et al. Acetaldehyde production by non-pathogenic Neisseria in human oral microflora: implications for carcinogenesis in upper aerodigestive tract. Int J Cancer. 2000; 88:342-50. [PubMed: 11054661]

39. Nieminen MT, Novak-Frazer L, Collins R, et al. Alcohol and acetaldehyde in African fermented milk mursik--a possible etiologic factor for high incidence of esophageal cancer in western Kenya. Cancer Epidemiol Biomarkers Prev. 2013; 22:69-75. [PubMed: 23155139]

40. Lin Y, Totsuka Y, He Y, et al. Epidemiology of esophageal cancer in Japan and China. J Epidemiol. 2013; 23:233-42. [PubMed: 23629646]

41. Yu H, Fu C, Wang J, et al. Interaction between XRCC1 polymorphisms and intake of long-term stored rice in the risk of esophageal squamous cell carcinoma: a case-control study. Biomed Environ Sci. 2011; 24:268-74. [PubMed: 21784313]

42. Chen J, Zhang N, Wakai T, et al. Effect of the interaction between the amount and duration of alcohol consumption and tobacco smoking on the risk of esophageal cancer: A case-control study. Exp Ther Med. 2010; 1:991-997. [PubMed: 22993631]

43. Wu MT, Lee YC, Chen CJ, et al. Risk of betel chewing for oesophageal cancer in Taiwan. Br J Cancer. 2001; 85:658-60. [PubMed: 11531247]

44. Lee CH, Lee JM, Wu DC, et al. Independent and combined effects of alcohol intake, tobacco smoking and betel quid chewing on the risk of esophageal cancer in Taiwan. Int J Cancer. 2005; 113:475-82. [PubMed: 15455377]

45. Tai SY, Wu IC, Wu DC, et al. Cigarette smoking and alcohol drinking and esophageal cancer risk in Taiwanese women. World J Gastroenterol. 2010; 16:1518-21. [PubMed: 20333794]

46. Wu IC, Lu CY, Kuo FC, et al. Interaction between cigarette, alcohol and betel nut use on esophageal cancer risk in Taiwan. Eur J Clin Invest. 2006; 36:236-41. [PubMed: 16620285]

47. Cheng KK, Day NE, Duffy SW, et al. Pickled vegetables in the aetiology of oesophageal cancer in Hong Kong Chinese. Lancet. 1992; 339:1314-8. [PubMed: 1349991]

48. Singh V, Singh LC, Singh AP, et al. Status of epigenetic chromatin modification enzymes and esophageal squamous cell carcinoma risk in northeast Indian population. Am J Cancer Res. 2015; 5:979-99. [PubMed: 26045981]

49. Sankaranarayanan R, Duffy SW, Padmakumary G, et al. Risk factors for cancer of the oesophagus in Kerala, India. Int J Cancer. 1991; 49:485-9. [PubMed: 1917146]

50. Segal I, Reinach SG, de Beer M. Factors associated with oesophageal cancer in Soweto, South Africa. Br J Cancer. 1988; 58:681-6. [PubMed: 3219281]

51. Pacella-Norman R, Urban MI, Sitas F, et al. Risk factors for oesophageal, lung, oral and laryngeal cancers in black South Africans. Br J Cancer. 2002; 86:1751-6. [PubMed: 12087462]

52. Dlamini Z, Bhoola K. Esophageal cancer in African blacks of Kwazulu Natal, South Africa: an epidemiological brief. Ethn Dis. 2005; 15:786-9. [PubMed: 16259509]

53. Patel K, Wakhisi J, Mining S, et al. Esophageal Cancer, the Topmost Cancer at MTRH in the Rift Valley, Kenya, and Its Potential Risk Factors. ISRN Oncol. 2013; 2013:503249. [PubMed: 24490085]

54. Almodova EC, de Oliveira WK, Machado LF, et al. Atrophic gastritis: risk factor for esophageal squamous cell carcinoma in a Latin-American population. World J Gastroenterol. 2013; 19:20604. [PubMed: 23599625] 
55. Castelletto R, Castellsague X, Munoz N, et al. Alcohol, tobacco, diet, mate drinking, and esophageal cancer in Argentina. Cancer Epidemiol Biomarkers Prev. 1994; 3:557-64. [PubMed: 7827585]

56. Castellsague X, Munoz N, De Stefani E, et al. Independent and joint effects of tobacco smoking and alcohol drinking on the risk of esophageal cancer in men and women. Int J Cancer. 1999; 82:657-64. [PubMed: 10417762]

57. De Stefani E, Munoz N, Esteve J, et al. Mate drinking, alcohol, tobacco, diet, and esophageal cancer in Uruguay. Cancer Res. 1990; 50:426-31. [PubMed: 2295081]

58. Garidou A, Tzonou A, Lipworth L, et al. Life-style factors and medical conditions in relation to esophageal cancer by histologic type in a low-risk population. Int J Cancer. 1996; 68:295-9. [PubMed: 8903469]

59. Franceschi S, Talamini R, Barra S, et al. Smoking and drinking in relation to cancers of the oral cavity, pharynx, larynx, and esophagus in northern Italy. Cancer Res. 1990; 50:6502-7. [PubMed: 2208109]

60. Lagergren J, Bergstrom R Fau, Lindgren A, Lindgren A Fau, Nyren O, et al. The role of tobacco, snuff and alcohol use in the aetiology of cancer of the oesophagus and gastric cardia. Int $\mathrm{J}$ Cancer. 2000; 85(3):340-6. [PubMed: 10652424]

61. Gallus S, Altieri A, Bosetti C, et al. Cigarette tar yield and risk of upper digestive tract cancers: case-control studies from Italy and Switzerland. Ann Oncol. 2003; 14:209-13. [PubMed: 12562646]

62. Garavello W, Negri E, Talamini R, et al. Family history of cancer, its combination with smoking and drinking, and risk of squamous cell carcinoma of the esophagus. Cancer Epidemiol Biomarkers Prev. 2005; 14:1390-3. [PubMed: 15941946]

63. Talamini G, Capelli P, Zamboni G, et al. Alcohol, smoking and papillomavirus infection as risk factors for esophageal squamous-cell papilloma and esophageal squamous-cell carcinoma in Italy. Int J Cancer. 2000; 86:874-8. [PubMed: 10842204]

64. Vioque J, Barber X, Bolumar F, et al. Esophageal cancer risk by type of alcohol drinking and smoking: a case-control study in Spain. BMC Cancer. 2008; 8:221. [PubMed: 18673563]

65. Yu MC, Garabrant DH, Peters JM, et al. Tobacco, alcohol, diet, occupation, and carcinoma of the esophagus. Cancer Res. 1988; 48:3843-8. [PubMed: 3378219]

66. Graham S, Marshall J, Haughey B, et al. Nutritional epidemiology of cancer of the esophagus. Am J Epidemiol. 1990; 131:454-67. [PubMed: 2301355]

67. Vaughan TL, Davis S, Kristal A, et al. Obesity, alcohol, and tobacco as risk factors for cancers of the esophagus and gastric cardia: adenocarcinoma versus squamous cell carcinoma. Cancer Epidemiol Biomarkers Prev. 1995; 4:85-92. [PubMed: 7742727]

68. Kim MK, Ko MJ, Han JT. Alcohol consumption and mortality from all-cause and cancers among 1.34 million Koreans: the results from the Korea national health insurance corporation's health examinee cohort in 2000. Cancer Causes Control. 2010; 21:2295-302. [PubMed: 20941640]

69. Islami F, Fedirko V, Tramacere I, et al. Alcohol drinking and esophageal squamous cell carcinoma with focus on light-drinkers and never-smokers: a systematic review and meta-analysis. Int $\mathrm{J}$ Cancer. 2011; 129:2473-84. [PubMed: 21190191]

70. Allen NE, Beral V, Casabonne D, et al. Moderate alcohol intake and cancer incidence in women. J Natl Cancer Inst. 2009; 101:296-305. [PubMed: 19244173]

71. Prabhu A, Obi KO, Rubenstein JH. The synergistic effects of alcohol and tobacco consumption on the risk of esophageal squamous cell carcinoma: a meta-analysis. Am J Gastroenterol. 2014; 109:822-7. [PubMed: 24751582]

72. Islami F, Boffetta P, van Schooten FJ, et al. Exposure to Polycyclic Aromatic Hydrocarbons Among Never Smokers in Golestan Province, Iran, an Area of High Incidence of Esophageal Cancer - a Cross-Sectional Study with Repeated Measurement of Urinary 1-OHPG in Two Seasons. Front Oncol. 2012; 2:14. [PubMed: 22655262]

73. Deziel NC, Wei WQ, Abnet CC, et al. A multi-day environmental study of polycyclic aromatic hydrocarbon exposure in a high-risk region for esophageal cancer in China. J Expo Sci Environ Epidemiol. 2013; 23:52-9. [PubMed: 22805987] 
74. Fagundes RB, Abnet CC, Strickland PT, et al. Higher urine 1-hydroxy pyrene glucuronide (1OHPG) is associated with tobacco smoke exposure and drinking mate in healthy subjects from Rio Grande do Sul. Brazil. BMC Cancer. 2006; 6:139. [PubMed: 16729889]

75. Abedi-Ardekani B, Kamangar F, Hewitt SM, et al. Polycyclic aromatic hydrocarbon exposure in oesophageal tissue and risk of oesophageal squamous cell carcinoma in north-eastern Iran. Gut. 2010; 59:1178-83. [PubMed: 20584779]

76. Cancer IAfRo. Betel-quid and areca-nut chewing and some areca-nut derived nitrosamines: IARC Monogr Eval Carcinog Risks Hum. 2004; 85:1-334. [PubMed: 15635762]

77. Wen CP, Tsai MK, Chung WS, et al. Cancer risks from betel quid chewing beyond oral cancer: a multiple-site carcinogen when acting with smoking. Cancer Causes Control. 2010; 21:1427-35. [PubMed: 20458529]

78. Akhtar S, Sheikh AA, Qureshi HU. Chewing areca nut, betel quid, oral snuff, cigarette smoking and the risk of oesophageal squamous-cell carcinoma in South Asians: a multicentre case-control study. Eur J Cancer. 2012; 48:655-61. [PubMed: 21733677]

79. Znaor A, Brennan P, Gajalakshmi V, et al. Independent and combined effects of tobacco smoking, chewing and alcohol drinking on the risk of oral, pharyngeal and esophageal cancers in Indian men. Int J Cancer. 2003; 105:681-6. [PubMed: 12740918]

80. Boonyaphiphat $\mathrm{P}$, Thongsuksai $\mathrm{P}$, Sriplung $\mathrm{H}$, et al. Lifestyle habits and genetic susceptibility and the risk of esophageal cancer in the Thai population. Cancer Lett. 2002; 186:193-9. [PubMed: 12213289]

81. Li WQ, Park Y, Wu JW, et al. Index-based dietary patterns and risk of esophageal and gastric cancer in a large cohort study. Clin Gastroenterol Hepatol. 2013; 11:1130-1136.e2. [PubMed: 23591281]

82. Abnet CC, Corley DA, Freedman ND, et al. Diet and upper gastrointestinal malignancies. Gastroenterology. 2015; 148:1234-1243.e4. [PubMed: 25680671]

83. Jeurnink SM, Buchner FL, Bueno-de-Mesquita HB, et al. Variety in vegetable and fruit consumption and the risk of gastric and esophageal cancer in the European Prospective Investigation into Cancer and Nutrition. Int J Cancer. 2012; 131:E963-73. [PubMed: 22392502]

84. Liang H, Fan JH, Qiao YL. Epidemiology, etiology, and prevention of esophageal squamous cell carcinoma in China. Cancer Biol Med. 2017; 14:33-41. [PubMed: 28443201]

85. Ren JS, Kamangar F, Forman D, et al. Pickled food and risk of gastric cancer--a systematic review and meta-analysis of English and Chinese literature. Cancer Epidemiol Biomarkers Prev. 2012; 21:905-15. [PubMed: 22499775]

86. Cheng SJ, Sala M, Li MH, et al. Mutagenic, transforming and promoting effect of pickled vegetables from Linxian county, China. Carcinogenesis. 1980; 1:685-92. [PubMed: 11272122]

87. Zhang WX, Xu MS, Wang GH, et al. Quantitative analysis of Roussin red methyl ester in pickled vegetables. Cancer Res. 1983; 43:339-41. [PubMed: 6847776]

88. Lu SH, Camus AM, Tomatis L, et al. Mutagenicity of extracts of pickled vegetables collected in Linhsien County, a high-incidence area for esophageal cancer in Northern China. J Natl Cancer Inst. 1981; 66:33-6. [PubMed: 7005503]

89. World Health Organization International Agency for Research on Cancer Pickled vegetables IARC Monographs Evaluating the Carcinogenic Risks to Humans. Vol. 56. World Health Organization; Geneva: 1993. p. 83-113.

90. Islami F, Ren JS, Taylor PR, et al. Pickled vegetables and the risk of oesophageal cancer: a metaanalysis. Br J Cancer. 2009; 101:1641-7. [PubMed: 19862003]

91. Seifried HE, McDonald SS, Anderson DE, et al. The antioxidant conundrum in cancer. Cancer Res. 2003; 63:4295-8. [PubMed: 12907593]

92. Kohen R, Nyska A. Oxidation of biological systems: oxidative stress phenomena, antioxidants, redox reactions, and methods for their quantification. Toxicol Pathol. 2002; 30:620-50. [PubMed: 12512863]

93. Byers T, Perry G. Dietary carotenes, vitamin C, and vitamin E as protective antioxidants in human cancers. Annu Rev Nutr. 1992; 12:139-59. [PubMed: 1503801] 
94. Mayne ST, Ferrucci LM, Cartmel B. Lessons learned from randomized clinical trials of micronutrient supplementation for cancer prevention. Annu Rev Nutr. 2012; 32:369-90. [PubMed: 22524186]

95. Fleming J, Ghose A, Harrison PR. Molecular mechanisms of cancer prevention by selenium compounds. Nutr Cancer. 2001; 40:42-9. [PubMed: 11799922]

96. Jiang Y, Du HZ, Zhu WY, et al. Effects of a regional Chinese diet and its vitamin supplementation on proliferation of human esophageal cancer cell lines. Biomed Environ Sci. 2008; 21:442-8. [PubMed: 19133620]

97. Gaziano JM, Sesso HD, Christen WG, et al. Multivitamins in the prevention of cancer in men: the Physicians' Health Study II randomized controlled trial. JAMA. 2012; 308:1871-80. [PubMed: 23162860]

98. Guallar E, Stranges S, Mulrow C, et al. Enough is enough: Stop wasting money on vitamin and mineral supplements. Ann Intern Med. 2013; 159:850-1. [PubMed: 24490268]

99. Wang JB, Abnet CC, Fan JH, et al. The randomized Linxian Dysplasia Nutrition Intervention Trial after 26 years of follow-up: no effect of multivitamin supplementation on mortality. JAMA Intern Med. 2013; 173:1259-61. [PubMed: 23712839]

100. Wei WQ, Abnet CC, Qiao YL, et al. Prospective study of serum selenium concentrations and esophageal and gastric cardia cancer, heart disease, stroke, and total death. Am J Clin Nutr. 2004; 79:80-5. [PubMed: 14684401]

101. Mark SD, Qiao YL, Dawsey SM, et al. Prospective study of serum selenium levels and incident esophageal and gastric cancers. J Natl Cancer Inst. 2000; 92:1753-63. [PubMed: 11058618]

102. Steevens J, van den Brandt PA, Goldbohm RA, et al. Selenium status and the risk of esophageal and gastric cancer subtypes: the Netherlands cohort study. Gastroenterology. 2010; 138:1704-13. [PubMed: 20006613]

103. Cai L, You NC, Lu H, et al. Dietary selenium intake, aldehyde dehydrogenase-2 and X-ray repair cross-complementing 1 genetic polymorphisms, and the risk of esophageal squamous cell carcinoma. Cancer. 2006; 106:2345-54. [PubMed: 16639733]

104. Cai X, Wang C, Yu W, et al. Selenium Exposure and Cancer Risk: an Updated Meta-analysis and Meta-regression. Sci Rep. 2016; 6:19213. [PubMed: 26786590]

105. Blot WJ, Li JY, Taylor PR, et al. Nutrition intervention trials in Linxian, China: supplementation with specific vitamin/mineral combinations, cancer incidence, and disease-specific mortality in the general population. J Natl Cancer Inst. 1993; 85:1483-92. [PubMed: 8360931]

106. Qiao YL, Dawsey SM, Kamangar F, et al. Total and cancer mortality after supplementation with vitamins and minerals: follow-up of the Linxian General Population Nutrition Intervention Trial. J Natl Cancer Inst. 2009; 101:507-18. [PubMed: 19318634]

107. Limburg PJ, Wei W, Ahnen DJ, et al. Randomized, placebo-controlled, esophageal squamous cell cancer chemoprevention trial of selenomethionine and celecoxib. Gastroenterology. 2005; 129:863-73. [PubMed: 16143126]

108. Loria D, Barrios E, Zanetti R. Cancer and yerba mate consumption: a review of possible associations. Rev Panam Salud Publica. 2009; 25:530-9. [PubMed: 19695149]

109. Islami F, Pourshams A, Nasrollahzadeh D, et al. Tea drinking habits and oesophageal cancer in a high risk area in northern Iran: population based case-control study. Bmj. 2009; 338:b929. [PubMed: 19325180]

110. Munishi MO, Hanisch R, Mapunda O, et al. Africa's oesophageal cancer corridor: Do hot beverages contribute? Cancer Causes Control. 2015; 26:1477-86. [PubMed: 26245249]

111. Yioris N, Ivankovic S, Lehnert T. Effect of thermal injury and oral administration of N-methyl-N'Nitro-N-nitrosoguanidine on the development of esophageal tumors in Wistar rats. Oncology. 1984; 41:36-8.

112. Kamangar F, Schantz MM, Abnet CC, et al. High levels of carcinogenic polycyclic aromatic hydrocarbons in mate drinks. Cancer Epidemiol Biomarkers Prev. 2008; 17:1262-8. [PubMed: 18483349]

113. Stefani ED, Moore M, Aune D, et al. Mate consumption and risk of cancer: a multi-site casecontrol study in Uruguay. Asian Pac J Cancer Prev. 2011; 12:1089-93. [PubMed: 21790257] 
114. Lahmann PH, Pandeya N, Webb PM, et al. Body mass index, long-term weight change, and esophageal squamous cell carcinoma: is the inverse association modified by smoking status? Cancer. 2012; 118:1901-9. [PubMed: 21960146]

115. Lindkvist B, Johansen D, Stocks T, et al. Metabolic risk factors for esophageal squamous cell carcinoma and adenocarcinoma: a prospective study of 580,000 subjects within the Me-Can project. BMC Cancer. 2014; 14:103. [PubMed: 24548688]

116. Wang SM, Fan JH, Jia MM, et al. Body mass index and long-term risk of death from esophageal squamous cell carcinoma in a Chinese population. Thorac Cancer. 2016; 7:387-92. [PubMed: 27385979]

117. Etemadi A, Golozar A, Kamangar F, et al. Large body size and sedentary lifestyle during childhood and early adulthood and esophageal squamous cell carcinoma in a high-risk population. Ann Oncol. 2012; 23:1593-600. [PubMed: 22052987]

118. Guo Y, Zhang T, Wang Z, et al. Body mass index and mortality in chronic obstructive pulmonary disease: A dose-response meta-analysis. Medicine (Baltimore). 2016; 95:e4225. [PubMed: 27428228]

119. Pinault L, Tjepkema M, Crouse DL, et al. Risk estimates of mortality attributed to low concentrations of ambient fine particulate matter in the Canadian community health survey cohort. Environ Health. 2016; 15:18. [PubMed: 26864652]

120. Xu H, Ho SS, Gao M, et al. Microscale spatial distribution and health assessment of PM2.5bound polycyclic aromatic hydrocarbons (PAHs) at nine communities in Xi'an, China. Environ Pollut. 2016; 218:1065-1073. [PubMed: 27577984]

121. Sapkota A, Zaridze D, Szeszenia-Dabrowska N, et al. Indoor air pollution from solid fuels and risk of upper aerodigestive tract cancers in central and eastern Europe. Environ Res. 2013; 120:90-5. [PubMed: 23092716]

122. Mlombe YB, Rosenberg NE, Wolf LL, et al. Environmental risk factors for oesophageal cancer in Malawi: A case-control study. Malawi Med J. 2015; 27:88-92. [PubMed: 26715952]

123. Freedman ND, Lacey JV Jr, Hollenbeck AR, et al. The association of menstrual and reproductive factors with upper gastrointestinal tract cancers in the NIH-AARP cohort. Cancer. 2010; 116:1572-81. [PubMed: 20186831]

124. Bodelon C, Anderson GL, Rossing MA, et al. Hormonal factors and risks of esophageal squamous cell carcinoma and adenocarcinoma in postmenopausal women. Cancer Prev Res (Phila). 2011; 4:840-50. [PubMed: 21505180]

125. Yu H, Liu G, Zhao P, et al. Hormonal and reproductive factors and risk of esophageal cancer in Chinese postmenopausal women: a case-control study. Asian Pac J Cancer Prev. 2011; 12:19536. [PubMed: 22292631]

126. Lu Y, Lagergren J. Reproductive factors and risk of oesophageal cancer, a population-based nested case-control study in Sweden. Br J Cancer. 2012; 107:564-9. [PubMed: 22767147]

127. Wynder EL, Hultberg S, Jacobsson F, et al. Environmental factors in cancer of the upper alimentary tract; a Swedish study with special reference to Plummer-Vinson (Paterson-Kelly) syndrome. Cancer. 1957; 10:470-87. [PubMed: 13460941]

128. Rosenberg PS, Alter BP, Ebell W. Cancer risks in Fanconi anemia: findings from the German Fanconi Anemia Registry. Haematologica. 2008; 93:511-7. [PubMed: 18322251]

129. Leeuwenburgh I, Scholten P, Alderliesten J, et al. Long-term esophageal cancer risk in patients with primary achalasia: a prospective study. Am J Gastroenterol. 2010; 105:2144-9. [PubMed: 20588263]

130. Morton LM, Gilbert ES, Hall P, et al. Risk of treatment-related esophageal cancer among breast cancer survivors. Ann Oncol. 2012; 23:3081-91. [PubMed: 22745217]

131. Abnet CC, Qiao YL, Mark SD, et al. Prospective study of tooth loss and incident esophageal and gastric cancers in China. Cancer Causes Control. 2001; 12:847-54. [PubMed: 11714113]

132. Chen H, Nie S, Zhu Y, et al. Teeth loss, teeth brushing and esophageal carcinoma: a systematic review and meta-analysis. Sci Rep. 2015; 5:15203. [PubMed: 26462879]

133. Abnet CC, Kamangar F, Islami F, et al. Tooth loss and lack of regular oral hygiene are associated with higher risk of esophageal squamous cell carcinoma. Cancer Epidemiol Biomarkers Prev. 2008; 17:3062-8. [PubMed: 18990747] 
134. Dar NA, Islami F, Bhat GA, et al. Poor oral hygiene and risk of esophageal squamous cell carcinoma in Kashmir. Br J Cancer. 2013; 109:1367-72. [PubMed: 23900216]

135. Guha N, Boffetta P, Wunsch FV, et al. Oral health and risk of squamous cell carcinoma of the head and neck and esophagus: results of two multicentric case-control studies. Am J Epidemiol. 2007; 166:1159-73. [PubMed: 17761691]

136. Abnet CC, Kamangar F, Dawsey SM, et al. Tooth loss is associated with increased risk of gastric non-cardia adenocarcinoma in a cohort of Finnish smokers. Scand J Gastroenterol. 2005; 40:6817. [PubMed: 16036528]

137. Nair J, Ohshima H, Nair UJ, et al. Endogenous formation of nitrosamines and oxidative DNAdamaging agents in tobacco users. Crit Rev Toxicol. 1996; 26:149-61. [PubMed: 8688158]

138. Yu G, Dye BA, Gail MH, et al. The association between the upper digestive tract microbiota by HOMIM and oral health in a population-based study in Linxian, China. 2014; 14:1110.

139. Chen X, Winckler B, Lu M, et al. Oral Microbiota and Risk for Esophageal Squamous Cell Carcinoma in a High-Risk Area of China. PLoS One. 2015; 10:e0143603. [PubMed: 26641451]

140. Nasrollahzadeh D, Malekzadeh R, Ploner A, et al. Variations of gastric corpus microbiota are associated with early esophageal squamous cell carcinoma and squamous dysplasia. Sci Rep. 2015; 5:8820. [PubMed: 25743945]

141. Gao S, Li S, Ma Z, et al. Presence of Porphyromonas gingivalis in esophagus and its association with the clinicopathological characteristics and survival in patients with esophageal cancer. Infect Agent Cancer. 2016; 11:3. [PubMed: 26788120]

142. Zhang SK, Guo LW, Chen Q, et al. Prevalence of human papillomavirus 16 in esophageal cancer among the Chinese population: a systematic review and meta-analysis. Asian Pac J Cancer Prev. 2014; 15:10143-9. [PubMed: 25556439]

143. Sitas F, Egger S, Urban MI, et al. InterSCOPE study: Associations between esophageal squamous cell carcinoma and human papillomavirus serological markers. J Natl Cancer Inst. 2012; 104:147-58. [PubMed: 22228147]

144. Halec G, Schmitt M, Egger S, et al. Mucosal alpha-papillomaviruses are not associated with esophageal squamous cell carcinomas: Lack of mechanistic evidence from South Africa, China and Iran and from a world-wide meta-analysis. Int J Cancer. 2016; 139:85-98. [PubMed: 26529033]

145. Integrated genomic characterization of oesophageal carcinoma. Nature. 2017; 541:169-175. [PubMed: 28052061]

146. Liu W, Snell JM, Jeck WR, et al. Subtyping sub-Saharan esophageal squamous cell carcinoma by comprehensive molecular analysis. JCI Insight. 2016; 1:e88755. [PubMed: 27734031]

147. Chen T, Cheng H, Chen X, et al. Family history of esophageal cancer increases the risk of esophageal squamous cell carcinoma. Sci Rep. 2015; 5:16038. [PubMed: 26526791]

148. Gao Y, Hu N, Han X, et al. Family history of cancer and risk for esophageal and gastric cancer in Shanxi, China. BMC Cancer. 2009; 9:269. [PubMed: 19656375]

149. Blaydon DC, Etheridge SL, Risk JM, et al. RHBDF2 mutations are associated with tylosis, a familial esophageal cancer syndrome. Am J Hum Genet. 2012; 90:340-6. [PubMed: 22265016]

150. Marger RS, Marger D. Carcinoma of the esophagus and tylosis. A lethal genetic combination. Cancer. 1993; 72:17-9. [PubMed: 8508402]

151. Brooks PJ, Enoch MA, Goldman D, et al. The alcohol flushing response: an unrecognized risk factor for esophageal cancer from alcohol consumption. PLoS Med. 2009; 6:e50. [PubMed: 19320537]

152. Yokoyama T, Yokoyama A, Kato H, et al. Alcohol flushing, alcohol and aldehyde dehydrogenase genotypes, and risk for esophageal squamous cell carcinoma in Japanese men. Cancer Epidemiol Biomarkers Prev. 2003; 12:1227-33. [PubMed: 14652286]

153. Abnet CC, Freedman ND, Hu N, et al. A shared susceptibility locus in PLCE1 at 10q23 for gastric adenocarcinoma and esophageal squamous cell carcinoma. Nat Genet. 2010; 42:764-7. [PubMed: 20729852]

154. Abnet CC, Wang Z, Song X, et al. Genotypic variants at 2q33 and risk of esophageal squamous cell carcinoma in China: a meta-analysis of genome-wide association studies. Hum Mol Genet. 2012; 21:2132-41. [PubMed: 22323360] 
155. Wang LD, Zhou FY, Li XM, et al. Genome-wide association study of esophageal squamous cell carcinoma in Chinese subjects identifies susceptibility loci at PLCE1 and C20orf54. Nat Genet. 2010; 42:759-63. [PubMed: 20729853]

156. Wu C, Hu Z, He Z, et al. Genome-wide association study identifies three new susceptibility loci for esophageal squamous-cell carcinoma in Chinese populations. Nat Genet. 2011; 43:679-84. [PubMed: 21642993]

157. Wu C, Wang Z, Song X, et al. Joint analysis of three genome-wide association studies of esophageal squamous cell carcinoma in Chinese populations. Nat Genet. 2014; 46:1001-6. [PubMed: 25129146]

158. Wu C, Kraft P, Zhai K, et al. Genome-wide association analyses of esophageal squamous cell carcinoma in Chinese identify multiple susceptibility loci and gene-environment interactions. Nat Genet. 2012; 44:1090-7. [PubMed: 22960999]

159. McKay JD, Truong T, Gaborieau V, et al. A genome-wide association study of upper aerodigestive tract cancers conducted within the INHANCE consortium. PLoS Genet. 2011; 7:e1001333. [PubMed: 21437268]

160. Bai Y, Edamatsu H, Maeda S, et al. Crucial role of phospholipase Cepsilon in chemical carcinogen-induced skin tumor development. Cancer Res. 2004; 64:8808-10. [PubMed: 15604236]

161. Li M, Edamatsu H, Kitazawa R, et al. Phospholipase Cepsilon promotes intestinal tumorigenesis of $\mathrm{Apc}(\mathrm{Min} /+)$ mice through augmentation of inflammation and angiogenesis. Carcinogenesis. 2009; 30:1424-32. [PubMed: 19458037]

162. Bye H, Prescott NJ, Lewis CM, et al. Distinct genetic association at the PLCE1 locus with oesophageal squamous cell carcinoma in the South African population. Carcinogenesis. 2012; 33:2155-61. [PubMed: 22865593]

163. Mavaddat N, Pharoah PD, Michailidou K, et al. Prediction of breast cancer risk based on profiling with common genetic variants. J Natl Cancer Inst. 2015; 107

164. Pourshams A, Khademi H, Malekshah AF, et al. Cohort Profile: The Golestan Cohort Study--a prospective study of oesophageal cancer in northern Iran. Int J Epidemiol. 2010; 39:52-9. [PubMed: 19332502]

165. McCormack VA, Menya D, Munishi MO, et al. Informing etiologic research priorities for squamous cell esophageal cancer in Africa: A review of setting-specific exposures to known and putative risk factors. Int J Cancer. 2017; 140:259-271. [PubMed: 27466161] 


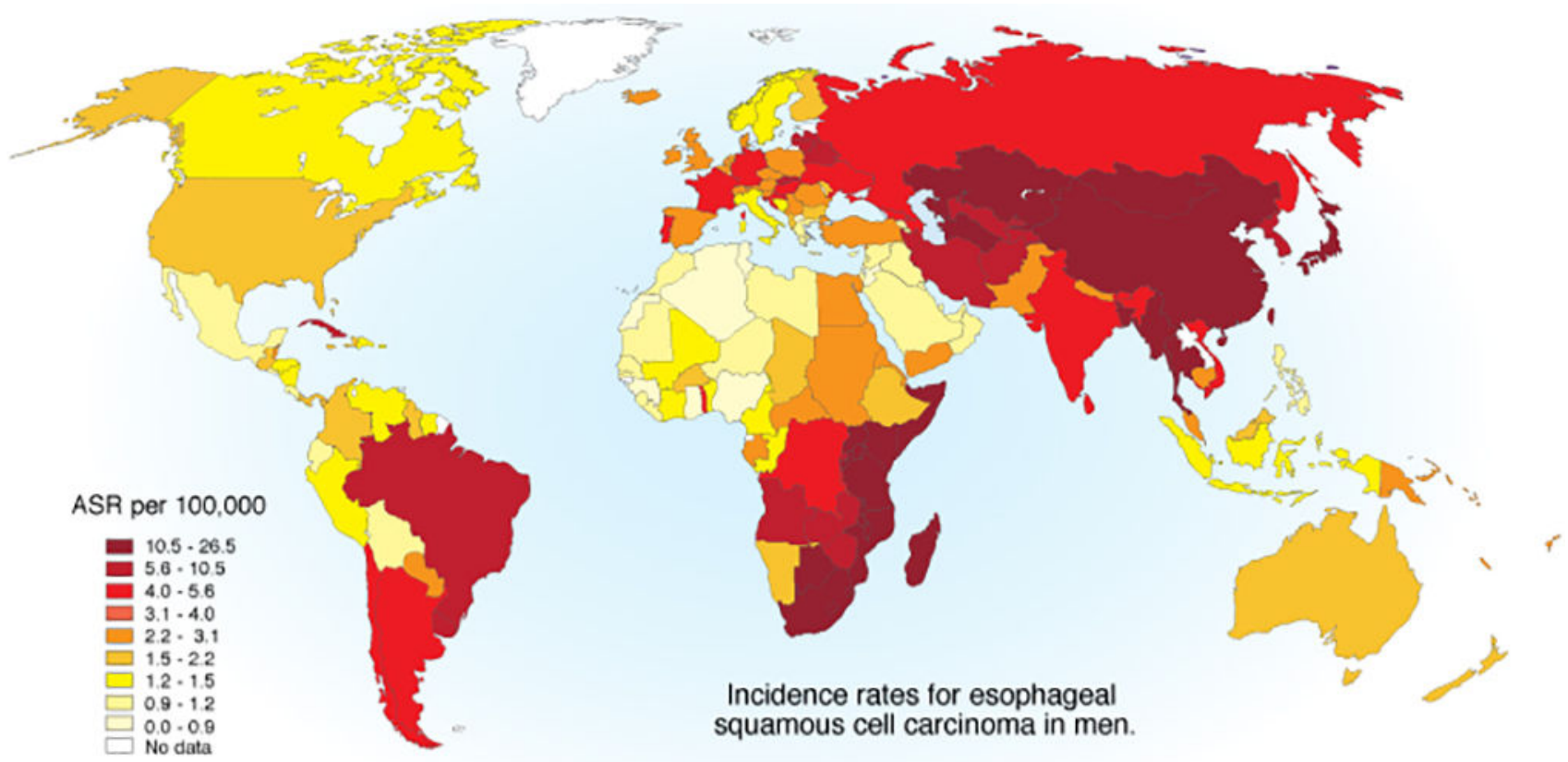

Figure 1.

Incidence rates for esophageal squamous cell carcinoma in men ${ }^{1}$ 


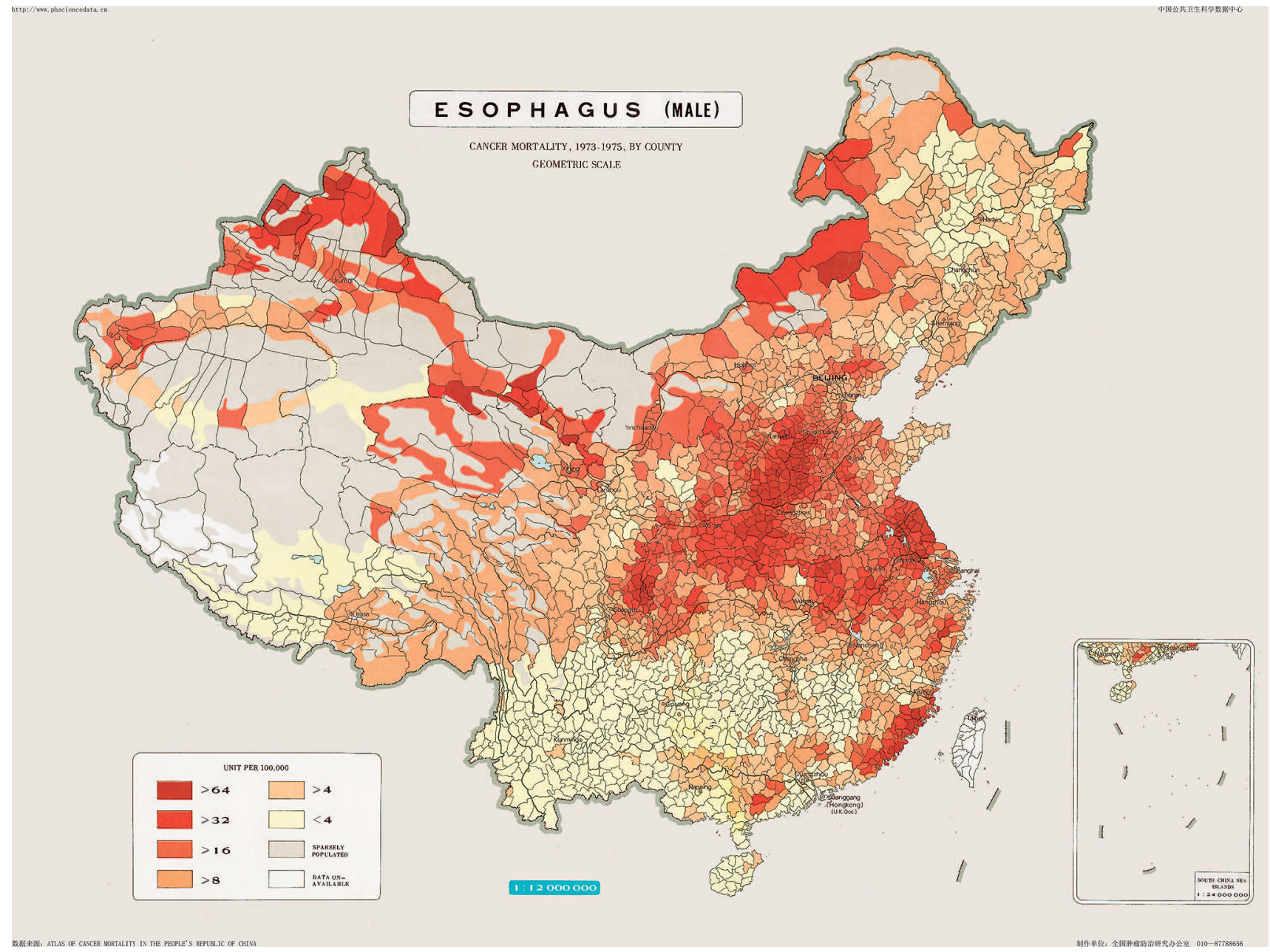

Figure 2.

Esophageal cancer mortality rates in men by county in the People's Republic of China 1973-1975. Used with permission from the National Office for Cancer Prevention and Control, National Cancer Center, Beijing, People's Republic of China 


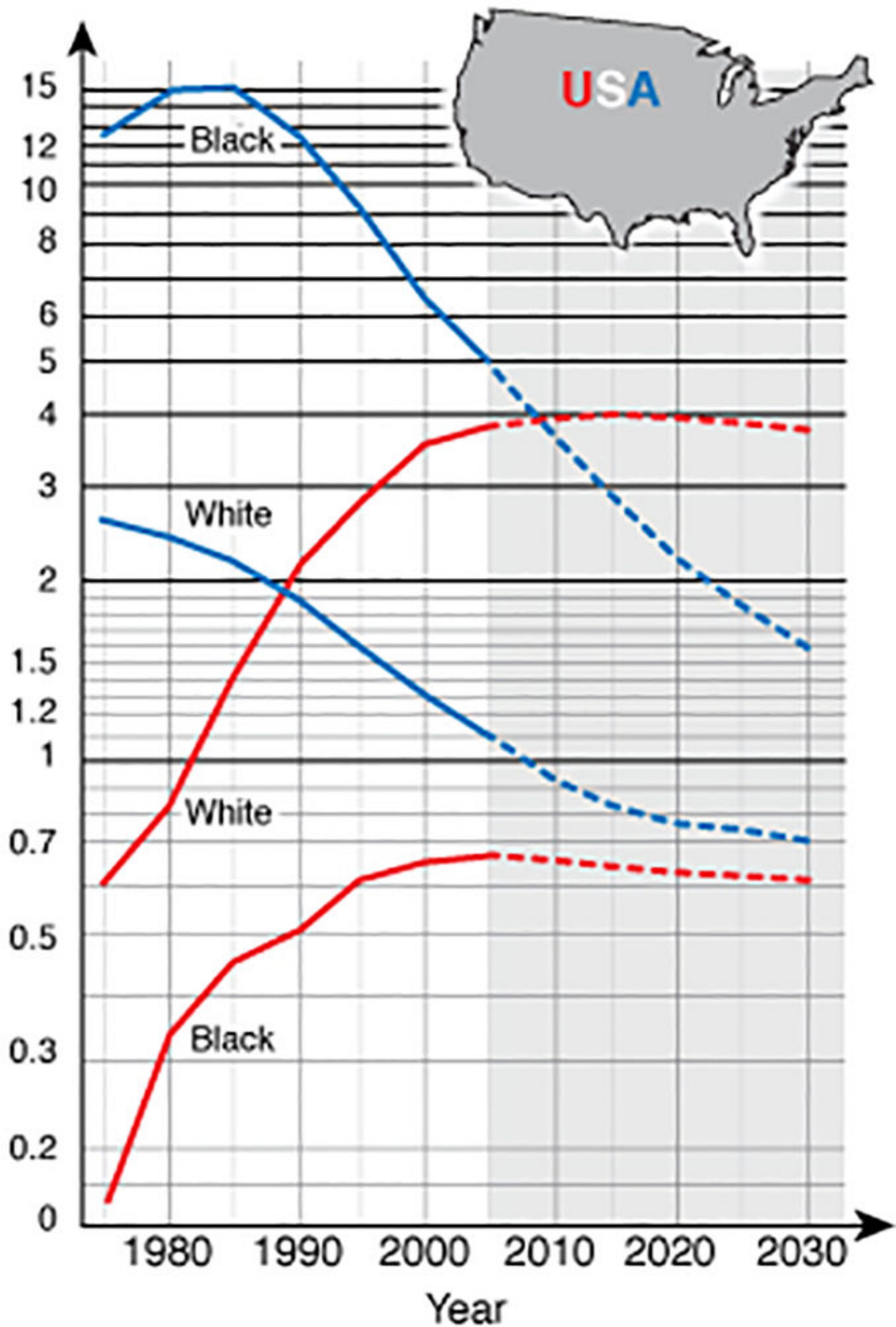

Figure 3.

Esophageal cancer rates by cell type and race in the United States. Blue lines indicate incidence rates for esophageal squamous cell carcinoma, and red lines indicate incidence rates for adenocarcinoma (adapted from ${ }^{11}$ ). 


\section{Table 1}

Risk factors for esophageal squamous cell carcinoma

\begin{tabular}{|c|c|}
\hline Exposure & Comments \\
\hline \multicolumn{2}{|c|}{ Risk factors with consistent evidence for causation } \\
\hline Tobacco & Smoking cigarette, pipe, cigar, hookah, and chewing tobacco \\
\hline Betel quid & Chewing with or without tobacco \\
\hline Pickled vegetables & Traditional Chinese methods of pickling without vinegar \\
\hline Hot foods & Thermal injury from maté, tea, soup, porridge \\
\hline $\mathrm{X}$ - and $\gamma$-radiation & Medical settings \\
\hline \multicolumn{2}{|c|}{ Risk factors with repeatedly reported associations, but not confirmed } \\
\hline Polycyclic aromatic hydrocarbons & Strong ecologic evidence, but few studies with individual exposure metrics \\
\hline Poor oral health & Includes loss of teeth and poor oral hygiene. Seen in most but not all studies where it was tested \\
\hline Reproductive factors & Limited evidence and residual confounding might explain current literature \\
\hline Gastric atrophy & Shown repeatedly in Nordic studies, but mixed evidence in other populations \\
\hline Opium & Multiple recent reports for opium users, but unclear if other forms of opiates would be implicated \\
\hline
\end{tabular}

